\title{
Selection of Single-Chain Variable Fragment Antibodies to Black Currant Reversion Associated Virus from a Synthetic Phage Display Library
}

\author{
Petri Susi, Angelika Ziegler, and Lesley Torrance
}

First author: Department of Plant Production, P.O. Box 27, 00014 University of Helsinki, Helsinki, and Department of Biology, Plant Physiology, and Molecular Biology, 20014 University of Turku, Turku, Finland; and second and third authors: Virology Department, Scottish

Crop Research Institute, Invergowrie, Dundee DD2 5DA, United Kingdom. Accepted for publication 3 December 1997.

\begin{abstract}
Susi, P., Ziegler, A., and Torrance, L. 1998. Selection of single-chain variable fragment antibodies to black currant reversion associated virus from a synthetic phage display library. Phytopathology 88:230-233.

Single-chain variable fragment ( $\mathrm{scFv}$ ) antibodies that bind to black currant reversion associated virus (BRAV) were obtained from a synthetic phage display antibody gene library without recourse to animal immunizations. Several different BRAV-specific phage $\mathrm{scFv}$ were obtained quickly, after only three rounds of selection against immobilized virus antigen. The phage scFv gave enzyme-linked immunosorbent assay (ELISA) absorbance values that were greater than seven times the control healthy plant extracts. In contrast, comparative tests using a rabbit antiserum failed, because unacceptably high background values were ob-
\end{abstract}

ABSTRACT tained with healthy plant extracts. Two of the $\mathrm{scFv}$ were subcloned into the pDAP2 vector for the rapid and efficient production of scFv-alkaline phosphatase fusion proteins. Functional fusion proteins were obtained after expression in Escherichia coli, and preparations from periplasmic extracts detected BRAV in ELISA. The results demonstrate that antibody fragments obtained from a synthetic phage display library are useful research tools, and they proved to be a viable practical alternative when traditional antisera failed to detect BRAV, a weak immunogen. Furthermore, the genetic fusion of antibody fragments to alkaline phosphatase obviates the need for further chemical coupling procedures, and the fusion proteins can be obtained cheaply.

Additional keywords: virus detection.
The use of antibodies in plant virology has provided the means to diagnose, and thus assist in the control of, virus diseases by the application of different immunoassays such as enzyme-linked immunosorbent assay (ELISA) and western blotting. Also, useful information on plant-virus interactions and the epidemiology of viruses has been obtained by the application of monoclonal antibodies (15). However, the production of monoclonal antibodies of sufficient specificity is usually a tedious process, requiring both expertise and expensive equipment. Moreover, the specificity and affinity of the resultant antibodies depend, to a large extent, on the animal's immune response. Recently, new methodology to produce specific antibodies in bacteria has been introduced $(5,13)$. In this system, functional fragments of antibody molecules are expressed, fused to the minor coat protein pIII, on the surface of filamentous bacteriophage (phage display). The antibody fragments comprise the heavy and light chain variable (antigen-binding) domains of antibody molecules linked by 15 amino acids to form a single polypeptide chain ( $\mathrm{scFv}$ ). Clones encoding specific fragments can be selected from large combinatorial phage display scFv libraries $(14,16,18)$. The clones are selected quickly and without recourse to animal immunizations.

Black currant reversion is the most economically important disease of black currants (Ribes nigrum L.). It has been reported in all countries where black currant is grown commercially, with the exception of the Americas; and despite 50 years of research, the causal agent is still unknown. It is a virus-like disease that is transmitted in nature by the eriophyid gall mite (Cecidophyopsis ribis Westw.) and experimentally by graft-inoculation (1). Re-

Corresponding author: L. Torrance; E-mail address: 1torra@scri.sari.ac.uk

Publication no. P-1998-0112-02R

(C) 1998 The American Phytopathological Society cently, a new nepovirus associated with the disease was isolated from black currant leaves showing symptoms of reversion and cultured in Chenopodium quinoa. The virus was given the name black currant reversion associated virus (BRAV) (10). BRAV is a weak immunogen, and the polyclonal antisera that have been produced have contained high titers of antibodies to plant components (10). The antibodies were incorporated into an immunocapture reverse transcriptase-polymerase chain reaction (RT-PCR) method to detect BRAV, but the polyclonal antiserum was not suitable for use in ELISA. Moreover, it has not been possible to obtain a polyclonal antiserum that works well in ELISA, despite six attempts and using as immunogens either purified virus preparations or bands of coat protein excised from polyacrylamide gels (P. Susi, S. Latvala, A. Lemmetty, and K. Lehto, unpublished data). Production of specific antibodies would greatly benefit epidemiological and molecular studies of BRAV and make large-scale testing of black currant samples much cheaper.

An advantage of the antibody library approach, and selection of $\mathrm{scFv}$ by phage display, is that it overcomes the problems associated with weak immunogens, because it does not rely on stimulation of the immune system. Recently, phage display methodology has been used to obtain scFv specific for cucumber mosaic cucumovirus and potato leafroll luteovirus $(3,19)$. Therefore, since difficulties have been experienced in trying to raise antibodies by conventional methods, we decided to test whether reagents suitable for use in epidemiological and molecular studies of BRAV could be obtained from a synthetic phage display library.

\section{MATERIALS AND METHODS}

Virus purification. BRAV was purified from leaves of $C$. quinoa as described (10). Virus concentration was determined by electrophoresis of samples in sodium dodecyl sulfate-polyacryla- 
mide gel electrophoresis (SDS-PAGE) and comparison of the intensity of Coomassie blue-stained bands against dilutions of bovine serum albumin (BSA; 1 to $20 \mu \mathrm{g}$ per lane) standards. The virus particles were suspended in $0.05 \mathrm{M}$ citrate buffer, $\mathrm{pH} 7$, and used for ELISA and coating immunotubes for library selections as described below.

Selection from phage library. The scFv were obtained from the Medical Research Council (Cambridge, United Kingdom) human synthetic scFv library 2, which contains more than $10^{8}$ clones and has been constructed in vitro using PCR to amplify the sequence encoding the variable regions $\left(\mathrm{V}_{\mathrm{H}}\right.$ [heavy chain variable domain] and $V_{L}$ [light chain variable domain]) of human immunoglobulins. The $\mathrm{V}_{\mathrm{H}}$ and $\mathrm{V}_{\mathrm{L}}$ domains contain three complementarity determining regions (CDRs) of hypervariable sequence, and the variation in these regions is largely responsible for the specificity of binding to antigen. PCRs were devised to produce DNA encoding 50 germ line $\mathrm{V}_{\mathrm{H}}$ gene segments (including CDR1 and CDR2) combined with CDR3s of between 4 and 12 amino acids in length encoded by random nucleotide sequences (14). The rearranged $V_{H}$ genes were then combined with a single $V_{\lambda} 3$ chain in the phagemid pHEN (4).

The library stock was amplified and particles were rescued by superinfection with helper phage VCS-M13 (Stratagene Inc., Cambridge, United Kingdom) (12,17). The scFv were selected from the phage library after three rounds of selection that were done essentially as follows: for each round of selection, immunotubes (Maxisorp; Nunc, Roskilde, Denmark) were coated with 10 to $50 \mu \mathrm{g}$ of BRAV particles per $\mathrm{ml}$ of $50 \mathrm{mM}$ carbonate (coating) buffer, $\mathrm{pH}$ 9.6 , overnight at room temperature (approximately $\left.22^{\circ} \mathrm{C}\right)(12,19)$. The tubes were then rinsed once with phosphate-buffered saline (PBS) and blocked with 2\% nonfat dried milk (Marvel; Premier Beverages, Stafford, United Kingdom) in PBS. The phage preparation was added to tubes at a concentration of $10^{12} \mathrm{CFU}$ and incubated for $2 \mathrm{~h}$ at room temperature. After extensive washing (20 times with PBS containing $0.05 \%$ Tween 20 and 20 times with PBS), the bound phage was eluted with $100 \mathrm{mM}$ triethylamine and then used to infect Escherichia coli. Phage particles were rescued by superinfection with helper phage.

Screening and sequencing of clones. For all cloning and DNA preparation procedures, the E. coli strain TG-1 was used. Phage was rescued from single ampicillin-resistant colonies using helper phage VCS-M13 (Stratagene Inc.) (13). scFv genes were subcloned

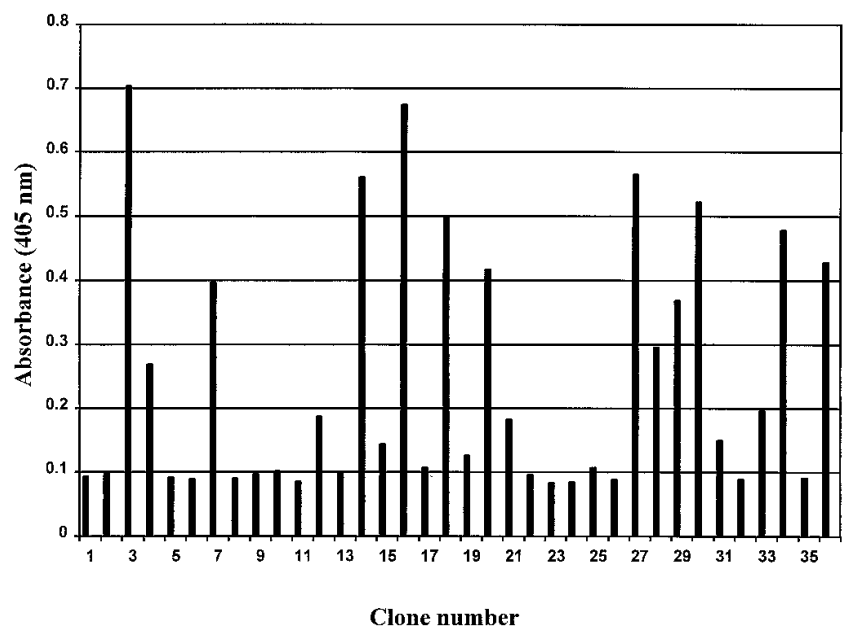

Fig. 1. Absorbance values $\left(A_{405 \mathrm{~nm}}\right)$ obtained in enzyme-linked immunosorbent assay of phage single-chain variable fragments from 36 single colonies tested after the third round of selection from the phage-display library. Wells of microtiter plates (Maxisorp; Nunc, Roskilde, Denmark) were coated with $5 \mu \mathrm{g}$ of purified black currant reversion associated virus particles per $\mathrm{ml}$ overnight at $4^{\circ} \mathrm{C}$. $A_{405 \mathrm{~nm}}$ was measured after $1 \mathrm{~h}$ of incubation with substrate at room temperature (approximately $22^{\circ} \mathrm{C}$ ). into the pDAP2 vector (8), and production of $\mathrm{scFv}$ antibodies was induced by isopropyl- $\beta$-thiogalactoside (IPTG). Preparations containing either phage or $\mathrm{scFv}$ antibodies (supernatant $[\mathrm{SN}]$ or periplasmic [PE] extracts) (19) were screened for binding to antigen by ELISA. The nucleotide sequences of $\mathrm{scFv}$ genes from phage $\mathrm{scFv}$ that exhibited specific binding in ELISA were sequenced, and the sequences were analyzed using the V-base sequence directory (available online from MRC; I. M. Tomlinson, S. C. Williams, S. J. Corbett, J. P. L. Cox, and G. Winter, MRC Centre for Protein Engineering, Cambridge, United Kingdom) and the Kabat database (6).

Phage and plate-trapped antigen (PTA) ELISA. Microtiter plates (Nunc Immunoplate II; Nunc) were coated with either 1 or $5 \mu \mathrm{g}$ of BRAV per ml of coating buffer overnight at $4^{\circ} \mathrm{C}$, and incubated with phage $\mathrm{scFv}$ particles and then with polyclonal antiM13 alkaline phosphatase (AP) conjugate (19) or with scFv-AP fusion proteins. After washing three times with PBS containing $0.05 \%$ Tween 20 and three times with PBS, substrate ( $p$-nitrophenyl phosphate; Sigma Chemical Co., Dorset, United Kingdom) was added at a concentration of $1 \mathrm{mg} \mathrm{ml}^{-1}$ in $10 \%$ diethanolamine buffer, $\mathrm{pH} 9.8$.

\section{RESULTS}

After three rounds of selection on BRAV antigen-coated tubes, 200 single colonies secreting phage $\mathrm{scFv}$ antibodies were tested for binding to purified BRAV particles. Some of these gave absorbance values $\left(A_{405 \mathrm{~nm}}\right)$ similar to the negative control wells coated with BSA, but a proportion gave values greater than two times background, and representative $A_{405 \mathrm{~nm}}$ values obtained from phage scFv produced from 36 single colonies are given in Figure 1. The clones were tested for the presence of $\mathrm{scFv}$ insert by restriction enzyme analysis, and some of the clones that gave $A_{405 \mathrm{~nm}}$ values of $<0.2$ did not contain an insert. Nucleotide sequences were determined for the $\mathrm{scFv}$ genes from six single colonies (code-named $14,15,16,20,27$, and 30) that gave $A_{405 \mathrm{~nm}}$ values of $>0.40$ in ELISA. All six sequences were found to be typical of $\mathrm{scFv}$ genes and were derived from $V_{H}$ germ line genes (which contribute CDR1 and CDR2) in family 3. The sequences of clones 14 and 15 and of clones 20 and 30 were identical. The nucleotide sequences of clones 14 and 16 were different (Fig. 2), particularly in the length of the CDR3 (the most variable portion of the antibody molecule). The CDR3 of clone 14 was five amino acids, whereas, in clone 16, it was 10 amino acids.

Since the sequences of clones 14 and 16 were clearly different and they gave the strongest reactions in phage ELISA, they were

\section{CDR1}

$\begin{array}{ll}\text { Clone } 14 & \text { EVQLVESGGGLVQPGGSLRLSCAASGFTFS SYSMN WVROAPGKG } \\ \text { Clone } 16 & \text { EVQLVESGGGLVQPGRSLRLSCAASGFTFS SYAMN WVRQAPGKG }\end{array}$

CDR2

Clone 14 LEWVS YISSSSSTIYYADSVKG RFTISRDNAKNSLYLQMNSLRD

Clone 16 LEWVA VISYDGSNKYYADSVKG RFTISRDNSKNTIYLQNNSLRA

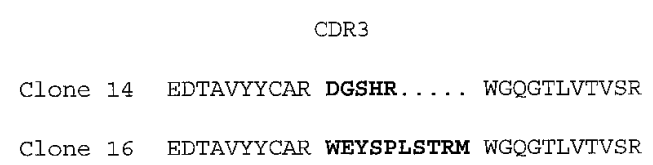

Fig. 2. Deduced amino acid sequences of the $V_{H}$ domains of two black currant reversion associated virus-specific single-chain variable fragments. Complementarity determining regions (CDR) are shown in boldface. 
chosen for further study. The two phage scFv were tested in PTA ELISA, in which the wells of microtiter plates were coated with purified BRAV preparation $\left(1 \mu \mathrm{g} \mathrm{ml}^{-1}\right)$ or noninfected $C$. quinoa extracts ( $1 \mathrm{~g}$ extracted in $4 \mathrm{ml}$ of coating buffer) as a negative control. The mean $A_{405 \mathrm{~nm}}$ value, obtained from three experiments, with phage $\mathrm{scFv} 14$ was 0.75 , and with phage scFv16 was 0.94 (the mean control value was 0.1 with both), so the phage $\mathrm{scFv}$ gave $A_{405 \mathrm{~nm}}$ values of between seven and nine times the negative control. In contrast, an experiment with polyclonal antiserum (raised against BRAV particles purified by the same method as described for the library selections) (10) gave $A_{405 \mathrm{~nm}}$ values of 2.25 for BRAV particles and 2.40 for healthy $C$. quinoa.

The $\mathrm{scFv}$ genes were subcloned into the $\mathrm{pDAP} 2$ vector (8), and soluble scFv antibodies fused to alkaline phosphatase (scFv-AP) were produced in E. coli. It has been shown that factors such as temperature and length of the induction period can influence the yield of scFv-AP fusion proteins obtained in cultures; therefore, these parameters were investigated to obtain optimal expression of the $\mathrm{scFv}$. We found that growth of bacteria and induction with IPTG at $16^{\circ} \mathrm{C}$ instead of $30^{\circ} \mathrm{C}$ resulted in increased total amounts of fusion proteins (determined by measuring alkaline phosphatase activity), and two times more scFv accumulated in the PE than the $\mathrm{SN}$ (data not shown). Most scFv accumulated in the PE after 2 days of induction with IPTG, and the concentration decreased slowly, because of leakage into the supernatant, if longer induction times were used. There was no apparent difference in using different media (Luria-Bertani broth and Tryptone-yeast broth) in the cultures. However, use of Tryptone-yeast broth seemed to result in increased background control values in ELISA (data not shown). Our results suggest that a lower induction temperature may facilitate the amount of functional $\mathrm{scFv}$ produced in E. coli.

The scFv-AP fusion proteins were tested for binding to different antigens in ELISA (Fig. 3). They readily detected purified BRAV antigen, and $A_{405 \mathrm{~nm}}$ values of 0.5 to 1.1 were obtained with purified BRAV when used at coating concentrations of $0.1 \mu \mathrm{g} \mathrm{ml}{ }^{-1}$, equivalent to approximately $10 \mathrm{ng}$ per well. BRAV was also detected in extracts of infected $C$. quinoa. The $A_{405 \mathrm{~nm}}$ values obtained with these samples were at least three times more than the values obtained in the control wells (noninfected $C$. quinoa extracts). In addition, the $A_{405 \mathrm{~nm}}$ values obtained from wells coated

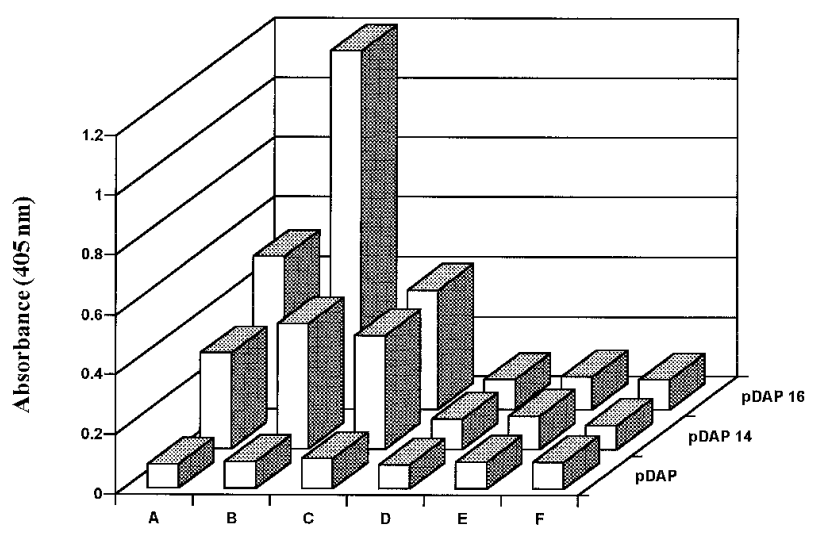

Fig. 3. Enzyme-linked immunosorbent assay to test the specificity of singlechain variable fragment $(\mathrm{scFv})$-alkaline phosphatase fusion proteins. Wells of microtiter plates (Maxisorp; Nunc, Roskilde, Denmark) were coated with antigen $(1 \mu \mathrm{g}$ of purified black currant reversion associated virus [BRAV] particles per $\mathrm{ml} ; 10 \mu \mathrm{g}$ of rubisco per $\mathrm{ml}$; or leaf extracted at $1 \mathrm{~g}$ in $4 \mathrm{ml}$ of coating buffer) overnight at $4^{\circ} \mathrm{C}$. Samples were incubated with coated wells for $3 \mathrm{~h}$ at room temperature (approximately $22^{\circ} \mathrm{C}$ ). $\mathrm{A}=\mathrm{scFv}$ from bacterial supernatant fluids on BRAV-coated well. $\mathrm{B}=\mathrm{scFv}$-containing periplasmic extract (PE) on BRAV-coated well. $\mathrm{C}=\mathrm{PE}$ on BRAV-infected Chenopodium quinoa-coated well. $\mathrm{D}=\mathrm{PE}$ on arabis mosaic virus-infected $C$. quinoa-coated well. $\mathrm{E}=\mathrm{PE}$ on noninfected $C$. quinoa-coated well. $\mathrm{F}=\mathrm{PE}$ on rubiscocoated well. $A_{405 \mathrm{~nm}}$ was measured after overnight (approximately $16 \mathrm{~h}$ ) incubation with substrate at $4^{\circ} \mathrm{C}$. with arabis mosaic virus (ArMV)-infected C. quinoa extracts or ribulose 1,5-biphosphate carboxylase (rubisco) were similar to those obtained with noninfected sap. These two additional controls were included, because infection of plants by unrelated nepoviruses can induce plant components that might bind nonspecifically to antisera (A. T. Jones, personal communication), and rubisco is a common component of plant extracts. These results indicated that binding of scFv-AP to BRAV was specific. Moreover, in the same experiment, samples were tested with a 1/500 dilution of a polyclonal antiserum (and anti-rabbit-AP conjugate used to reveal bound antibodies). No difference was found between the $A_{405 \mathrm{~nm}}$ values from either infected or noninfected plant extracts; they were 2.50, 2.70, 2.56, and 2.50 for BRAV particles, BRAV-infected extract, ArMV-infected extracts, and healthy $C$. quinoa, respectively. Neither scFv-AP preparation labeled BRAV protein after SDS-PAGE and western blotting.

\section{DISCUSSION}

The results presented in this paper have demonstrated the feasibility of using a synthetic phage display library approach to obtain $\mathrm{scFv}$ antibody fragments against a weak immunogen. Our results show that BRAV-specific scFv can be obtained from synthetic $\mathrm{scFv}$ libraries quickly (within weeks) and without recourse to animal immunizations. We obtained $\mathrm{scFv}$ that, when expressed as fusions to alkaline phosphatase, readily detected approximately $10 \mathrm{ng}$ of purified virus and gave clear positive $A_{405 \mathrm{~nm}}$ values in tests on extracts of BRAV-infected $C$. quinoa leaves. The scFv were shown to be specific for BRAV, and low $A_{405 \mathrm{~nm}}$ values (usually $<0.1$ ) were obtained with control extracts. The $\mathrm{scFv}$ preparations are clonal and are equivalent to monoclonal antibody preparations (although they are univalent, not bivalent, molecules), but the costs of production and maintenance of these clones are much less than for monoclonal antibodies. The results obtained with the $\mathrm{scFv}$ library are in complete contrast to the failure to produce a specific antiserum in rabbits. The six polyclonal sera that have been produced gave substantial cross-reactions with components of plant sap when used in ELISA (P. Susi, S. Latvala, A. Lemmetty, and K. Lehto, unpublished data).

The scFv will be of use, for example, in monitoring the effectiveness of different treatments to improve methods of virus purification and for affinity purification to improve the yield and quality of virus preparations. They are also suitable for the detection of BRAV in indicator plants. However, the scFv may not be suited for reliable detection in naturally infected black currants in which it has been shown that BRAV is present in low concentration and erratically distributed (9). Highly sensitive techniques such as RTPCR may be more appropriate than serological methods for this virus. Nevertheless, the sensitivity of tests with $\mathrm{scFv}$ can be improved by genetic manipulation. The vector pDAP2 contains the $E$. coli alkaline phosphatase gene that exhibits low specific activity. The specific activity of this gene was increased 35 -fold by making mutations in the enzyme active site, particularly the substitution of serine for aspartic acid at position 101 (11). Recently, a modified version of pDAP2 (namely $\mathrm{pDAP} 2 / \mathrm{S}$ ) has been described containing such a mutation (7), and scFv fusions to the modified enzyme gave improved ELISA values in tests to detect beet necrotic yellow vein virus. Subcloning our selected $\mathrm{scFv}$ into this vector should enable stronger $A_{405 \mathrm{~nm}}$ values to be obtained in the future that may be further enhanced by the use of chemiluminescent substrates.

Previously, we found that $\mathrm{scFv}$ specific for plant viruses obtained from the same synthetic library were of moderate affinity and concluded that further improvements in affinity (or avidity) such as chain shuffling (2) or selection from larger libraries (16) were necessary before they could be used as satisfactory alternatives to conventionally produced antibodies $(3,19)$. In this work, we have shown that, when the viral antigen induces a poor re- 
sponse resulting in the production of a poor quality antiserum, the $\mathrm{scFv}$ obtained provide useful and valid alternatives without further modification.

\section{ACKNOWLEDGMENTS}

This work was supported by the British Council and the Ministry of Education in Finland (P. Susi), and the Scottish Office Agriculture, Environment and Fisheries Department (A. Ziegler and L. Torrance). We thank G. Himmler, Institute for Applied Microbiology, University of Agriculture, Vienna, Austria, for the pDAP2 vector; G. Winter and J. Harrison, Centre for Protein Engineering, Medical Research Council, Cambridge, United Kingdom, for the MRC human synthetic library 2; W. J. McGavin, SCRI, Dundee, United Kingdom, for assistance in virus purification; A. Lemmetty, ARC, Jokioinen, Finland, for supplying the virus (BRAV); and S. M. Macintosh for assistance with the nucleotide sequencing.

\section{LITERATURE CITED}

1. Adams, A. N., and Thresh, J. M. 1987. Reversion of blackcurrant. Pages 133-136 in: Virus Diseases of Small Fruits. R. H. Converse, ed. U.S. Dep. Agric. Agric. Handbook 631.

2. Clackson, T., Hoogenboom, H. R., Griffiths, A. D., and Winter, G. 1991. Making antibody fragments using phage display libraries. Nature (Lond.) 352:624-628.

3. Harper, K., Kerschbaumer, R., Ziegler, A., Macintosh, S. M., Cowan, G. H., Himmler, G., Mayo, M. A., and Torrance, L. 1997. A scFv-alkaline phosphatase fusion protein which detects potato leafroll luteovirus in plant extracts by ELISA. J. Virol. Methods 63:237-242.

4. Hoogenboom, H. R., Griffiths, A. D., Johnson, K., Chiswell, D., Hudson, P., and Winter, G. 1991. Multi-subunit proteins on the surface of filamentous phage: Methodologies for displaying antibody ( $\mathrm{Fab}$ ) heavy and light chains. Nucleic Acids Res. 19:4133-4137.

5. Hoogenboom, H. R., and Winter, G. 1992. By-passing immunisation: Human antibodies from synthetic repertoires of germline $V_{H}$ gene segments rearranged in vitro. J. Mol. Biol. 227:381-388.

6. Kabat, E. A., Wu, T. T., Perry, H. M., Gottesman, K. S., and Foeller, C. 1991. Sequences of Proteins of Immunological Interest, 5th ed. Public Health Service, National Institute of Health, Washington, DC.

7. Kerschbaumer, R. J., Hirschl, S., Kaufmann, A., Ibl, M., Koenig, R., and
Himmler, G. 1997. Single-chain Fv fusion proteins suitable as coating and detection reagents in a double antibody sandwich enzyme-linked immunosorbent assay. Anal. Biochem. 249:219-227.

8. Kerschbaumer, R. J., Hirschl, S., Schwager, C., Ibl, M., and Himmler, G. 1996. pDAP2: A vector for construction of alkaline phosphatase fusionproteins. Immunotechnology 2:145-153.

9. Latvala, S., Susi, P., Lemmetty, A., Cox, S., Jones, A. T., and Lehto, K. 1997. Ribes host range and erratic distribution within plants of blackcurrant reversion associated virus provide further evidence for its probable role as causal agent of reversion disease. Ann. Appl. Biol. 131:283-295.

10. Lemmetty, A., Latvala, S., Jones, A. T., Susi, P., McGavin, W. J., and Lehto, K. 1997. Purification and properties of a new virus from black currant, its affinities with nepoviruses, and its close association with black currant reversion disease. Phytopathology 87:404-413.

11. Mandecki, W., Shallcross, M. A., Sowadski, J., and Tomazic-Allen, S 1991. Mutagenesis of conserved residues within the active site of Escherichia coli alkaline phosphatase yields enzymes with increased $k_{\text {cat }}$ Protein Eng. 4:801-804.

12. Marks, J. D., Hoogenboom, H. R., Bonnert, T. P., McCafferty, J., Griffiths, A. D., and Winter, G. 1991. By-passing immunisation: Human antibodies from V-gene libraries displayed on phage. J. Mol. Biol. 222:581-597.

13. McCafferty, J., Griffiths, A. D., Winter, G., and Chiswell, D. J. 1990 Phage antibodies: Filamentous phage displaying antibody variable domains. Nature (Lond.) 348:552-554.

14. Nissim, A., Hoogenboom, H. R., Tomlinson, I. M., Flynn, G., Midgley, C., Lane, D., and Winter, G. 1994. Antibody fragments from a single pot phage display library as immunochemical reagents. EMBO (Eur. Mol. Biol. Organ.) J. 13:692-698.

15. Torrance, L. 1995. Use of monoclonal antibodies in plant pathology. Eur. J. Plant Pathol. 101:351-363.

16. Vaughan, T. J., Williams, A. J., Pritchard, K., Osbourn, J. K., Pope, A. R., Earnshaw, J. C., McCafferty, J., Hodits, R. A., Wilton, J., and Johnson, K. S. 1996. Human antibodies with sub-nanomolar affinities isolated from a large non-immunized phage display library. Nature Biotechnol. 14:309-314.

17. Vieira, J., and Messing, J. 1987. Production of single-stranded plasmid DNA. Methods Enzymol. 153:3-11.

18. Winter, G., Griffiths, A. D., Hawkins, R. E., and Hoogenboom, H. R. 1994. Making antibodies by phage display technology. Ann. Rev. Immunol. 12:433-455.

19. Ziegler, A., Torrance, L., Macintosh, S. M., Cowan, G. H., and Mayo, M. A. 1995. Cucumber mosaic cucumovirus antibodies from a synthetic phage display library. Virology 214:235-238. 